\title{
A NOTE OF A ROUGH SINGULAR INTEGRAL OPERATOR
}

\author{
DASHAN FAN, KANGHUI GUO AND YiBIAO PAN ${ }^{1}$
}

Abstract. $L^{p}$ mapping properties will be established in this paper for singular Radon transforms with rough kernels, extending the results of Grafakos and Stefanov.

Mathematics subject classification (1991): 42B20, 42B25.

Key words and phrases: Singular integral, rough kernel, Hardy space.

\section{REFERENCES}

[1] A. J. AL-HASAN AND D. FAN, $L^{p}$ boundedness of a singular integral operator, Canadian Math. Bulletin, to appear.

[2] A. P. CALDERÓN AND A. ZYGMund, On existence of certain singular integrals, Acta. Math. 88 (1952), $85-129$.

[3] A. P. Calderón And A. Zygmund, On singular integrals, Amer. J. Math. 18 (1956) 289-309.

[4] W. C. ConnetT, Singular integrals near $L^{1}$, Proc. Sympos. Pure Math. of Amer. Math. Soc. (S. Wainger and G. Weiss, eds.) 35, I (1979), 163-165.

[5] L. ColzANI, Hardy Spaces on Sphere, Ph.D. Thesis, Washington University, St. Louis, MO, 1982.

[6] R. R. COIFMAN AND G. WeISS, Extensions of Hardy spaces and their use in analysis, Bull. Amer. Math. Soc. 83 (1977), 569-645.

[7] J. DUOANDIKOETXEA AND J. L. RUBIO DE FRANCIA, Maximal and singular integral operators via Fourier transform estimates, Invent. Math. 84 (1986), 541-561.

[8] D. FAN AND Y. PAN, $L^{2}$ boundedness of a singular integral operator, Publicacions Matemàtiques, 41 (1997), 317-333.

[9] D. FAN AND Y. PAN, Singular integral with rough kernels supported by subvarieties, Amer. J. Math. 119 (1997), 799-839.

[10] L. GRAFAKOS AND A. SteFANOv, $L^{p}$ bounds for singular integrals and maximal singular integrals with rough kernels, Indiana Univ. Math. J., to appear.

[11] F. RicCi AND G. WeISS, A characterization of $H^{1}\left(\sum_{n-1}\right)$, Proc. Sympos. Pure Math. of Amer. Math. Soc. (S. Wainger and G. Weiss, eds.), Vol. 35, I (1979), 289-294. 